\title{
Agrotechnical methods ofreducing root rot for cultivating spring wheat in organic farming
}

\author{
AlfiaRazina, ${ }^{1, *}$ \\ ${ }^{1}$ Irkutsk Research Institute of Agriculture, Irkutsk, Russia
}

\begin{abstract}
Energy-saving technologies of wheat cultivation limit the buffer role of the agrotechnical method in reducing the spread of root rot. This situation calls for using increased volumes of pesticides in order to decrease harvest losses arising from actions of harmful organisms, which does not allow to produce organic food.Considering this, evaluation of the efficiency of agrotechnical methods of cultivating spring wheat aimed at enhancing phytosanitary conditions of crops is very important. The goal of our work was to evaluate the role of predecessors, methods of soil preparation,organic fertilizers, new varieties of spring wheat, and the timing of planting in limiting the spread and reducing the harmfulness of root rot. Our study has been conducted in the forest-steppe zone of Eastern Siberia. We have established that green manure in crop rotationandfallow arable land with introduction of $30 \mathrm{t} / \mathrm{ha}$ of organic manure fertilizer with a disc harrow to a depth of 10-12 cmreduce the spread and severity of root rot and increase wheat yields. In the plantings of the new variety of spring wheat Marsianka, the spread of the disease was reliably less, and the yield was higher compared to the control variety Tulunskaya 11. The optimal planting date for the average of two years was May 25, the crops planted then compared to those planted on May 30 were $9.4 \%$ less affected by the disease and gave a reliable increase in the harvest of 0.15 tons/ha. Our studies have shown that during production of organic wheat we can limit the spread andharmfulness of root rot withagrotechnical methods.
\end{abstract}

\section{Introduction}

We can now state that the intensification of agricultural production based solely on chemicalpesticides has reached its limits. The emergence of the organic segment in the Agricultural Industry in many countries was a reaction to its over-chemicalization.Organic agriculture is practiced in 178 countries, of which 87 have their own regulatory framework. In 2018, Russia joined these countries $[1,2,3]$. The development of organic production in the Russian Federation is one of the significant reserves for increasing the volume and quality of crop products [4]. Plant protection should be aimed at strengthening food security while maintaining the health ofecosystems [5]. Agro-ecosystems that suppress plant soil pathogens are most in demand in plant disease management [6].

From the point of view of organic farming, agrotechnical methods have a special place in plant protection. Effective components of agrotechnical methods are crop rotations, soil treatment systems, optimal planting times, predecessors, using zoned seeds of disease-resistant and pest-resistant varieties [4], [7$10]$.

Various soil treatment systems, seed turnovers and organic fertilizers affect soil health and thus affect the sustainability of agro-ecosystems and sustainable agricultural development $[11,12]$.
In the Irkutsk region, energy-saving technologies are being introduced in adaptive landscape agriculture.These technologies limit the buffer role of the agrotechnical method in keeping the number of harmful organisms, in particular ones causing root rot, at a level below economic severity threshold. Lack of soil treatment and presence of plant residues lead to an increase in the number of soil pathogens of plants, increasing therisk ofdiseases [13].

All the wheat in this region cannot be accommodated on fallow arable land, as grain and livestock specialization while keeping animals in stalls requires concentrated grain feed and forces farmers to sow this crop after other grains or even after wheat. This situation requires the use of increased levels of pesticides to reduce crop losses from pests and prevents organic production. Which is why the evaluation of the effectiveness of agrotechnical methods of spring wheat cultivation in order to improve the phytosanitary condition of crops is important.

The goal of our work was to evaluate such agrotechnical techniques of wheat cultivation as predecessors, methods of soil preparation, organic fertilizers, new varieties of spring wheat, and the timing of planting in limiting the spread and reducing the harmfulness of root rot.

\footnotetext{
${ }^{*}$ Corresponding author: gnu nniish_nauka@mail.ru
} 


\section{Methods}

We have carried out field studies in experimental crop rotations on the experimental field of the Irkutsk Research Institute of Agriculture. The area of the experimentalfield is $70.0 \mathrm{~m}^{2}$. The experiment was repeated 3 times.

In experiments on studying predecessors, ways of processing soil, and planting dates we have used theBuryatskayaostistayavariety of spring wheat. The seeds were not treated with pesticides. In the experiments with spring wheat varieties, all the varieties:Tulunskaya 11 (control), Zoriana, and Marsianka are mid-season and bred in the department of crop breeding of the Irkutsk Research Institute of Agriculture (Irkutsk RIA).

Fertilizers were not introduced in the experiments considered in this article. Accounting for the spread of root rotwas conducted according to the methodology developed by the Russian Institute for Plant Protection(RIPP) [14]. The selection of sheaf samples and their analysis were carried out according to the state methodology of testing crop varieties[15]. Crop accounting was done per-field by direct combining with the Terrion combine. Statistical processing of grain yield data reduced to $14 \%$ moisture and $100 \%$ purity was carried out according to the B.A. Dospekhov's method of analysis of variance using the Snedecor V5 software package "Applied Statistics for Research" [16, 17].

The object of the research is the root rot of spring wheat, the main pathogens of which are Bipolarissorokiniana (Sacc.) Shoemaker. Syn.:Helminthosporium sativum Pammel, C.M. King et Bakke, H. sorokinianumSacc., Drechslerasorokiniana(Sacc.) Subram. Et P.C. Jain.; species ofFusarium (F. culmorum(W.G.Sm.) Sacc. var. culmorum, $F$. avenaceum(Fr.) Sacc. var. avenaceum, $F$. oxysporumSchltdl.var. oxysporum, $F$. graminearumSchwabe etc.); species of Alternaria (complex of species A. alternataetc.).

The years 2010-2016 in terms of moisture supply were characterized as arid, especially in the first half of the growing season; in some years, precipitation fell extremely unevenly with excess in the second half of vegetation period. The lackof precipitation during the vegetative period was $23.8 \%$ in $2012,44.9 \%$ in 2013 , $31.8 \%$ in $2014,38.3 \%$ in 2015 compared to the average long-term norm. In the first half of the growing season in 2016, the effects of summer-autumn droughts of the preceding 4 years were felt, and in August and September there was 1.2 times more rain than usual.

Vegetation periods in 2017-2018 were warm. In 2017, in May and the first decade of June, the plants were well-supplied with moisture, which contributed to the emergence of concurrent shoots and the foundation of future harvests. First and second decades of June and August were arid. In 2018, May and June were arid: there was 63 and $43.2 \%$ less precipitation than the norm, respectively, which contributed to the spread of wheat root rot and adversely affected crop formation. In general, the hydrothermal conditions during the years of the experiments allowed the crops to yield harvests at the average level.

\section{Results}

Field tests to assess the phytosanitary role of predecessors in relation to wheat root rot allowed to establish that, when clover green manure was used as a predecessor,spread of wheat root rot in the sproutphase was $33.8 \%$ lower and yields were higher by $0.59 \mathrm{t} / \mathrm{ha}$ (Table 1). Our result of reducing the amount of phytopathogen is not at odds with experimental data from other scientists on the positive role of green fertilizer use,including using legumes as green manure, in limiting the development of diseases to ensure the sustainability and productivity of agro-ecosystems. [1822]. Repeated seeding of wheat crops on the wheat predecessor increased the spread of the disease and lowered the yields by $30.3 \%$.

Table 1. Spread of root rot and wheat yields, depending on predecessors, average 2017-2018.

\begin{tabular}{|l|c|c|c|c|}
\hline \multirow{2}{*}{ Predecessor } & \multicolumn{2}{|c|}{$\begin{array}{c}\text { Spread of root rot, } \\
\text { \% }\end{array}$} & \multicolumn{2}{c|}{ Yields, t/ha } \\
\cline { 2 - 5 } & $\begin{array}{l}\text { Ave- } \\
\text { rage }\end{array}$ & $\begin{array}{l}\text { Difference } \\
\text { vs control }\end{array}$ & $\begin{array}{l}\text { Ave- } \\
\text { rage }\end{array}$ & $\begin{array}{c}\text { Difference } \\
\text { vs control }\end{array}$ \\
\hline Wheat(control) & 60.3 & - & 1.54 & - \\
\hline $\begin{array}{l}\text { Clover green } \\
\text { manure }\end{array}$ & 26.5 & -33.8 & 2.21 & 0.67 \\
\hline $\begin{array}{l}\text { Least } \\
\text { Significant } \\
\text { Difference } 05\end{array}$ & \multicolumn{3}{|c}{} \\
\hline
\end{tabular}

As a result of the study of the methods of basic soil preparation and use of organic fertilizer on fallow arable land(Table 2), we can observe the reliable positive effect of surface soil treatment with a disc harrow to a depth of 10-12 cm,which lead to reduction of the spread of root rot of spring wheat in the phase of harvesting regardless of the fertilization of the field.

Table 2. Effect of the method of basic soil preparation and use of manureon fallow arable land on the spread of root rot and wheat yields, average 2012-2016.

\begin{tabular}{|c|c|c|c|c|}
\hline \multirow{2}{*}{$\begin{array}{l}\text { Fertilizer } \\
\text { (Factor B) }\end{array}$} & \multicolumn{2}{|c|}{ Spread of root rot, \% } & \multicolumn{2}{|c|}{ Yields, $\mathrm{t} / \mathrm{ha}$} \\
\hline & Average & $\begin{array}{l}\text { Difference } \\
\text { vs control }\end{array}$ & Average & $\begin{array}{l}\text { Difference } \\
\text { vs control }\end{array}$ \\
\hline \multicolumn{5}{|c|}{ Soil treatment - Plowing 20-22 cm deep. (Factor A) } \\
\hline $\begin{array}{l}\text { No } \\
\text { fertilizer(control } \\
\text { ) }\end{array}$ & 26.2 & - & 2.69 & - \\
\hline Manure $30 \mathrm{t} / \mathrm{ha}$ & 29.5 & -3.3 & 3.0 & 0.31 \\
\hline \multicolumn{5}{|c|}{ Soil treatment -Disc harrow 10-12 cm deep.(Factor A) } \\
\hline No fertilizer & 32.3 & -6.1 & 2.84 & 0.15 \\
\hline Manure $30 \mathrm{t} / \mathrm{ha}$ & 32.6 & -6.4 & 3.07 & 0.38 \\
\hline $\begin{array}{l}\text { Least } \\
\text { Significant } \\
\text { Difference }_{05}\end{array}$ & & \begin{tabular}{|l}
3.4 \\
5.9 \\
B 8.3 \\
\end{tabular} & & $\begin{array}{l}.137 \\
0.337 \\
30.34 \\
\end{array}$ \\
\hline
\end{tabular}

A significant increase in the harvest is obtained when 30 tons per hectare of manure are introduced on fallow arable landwith both methods of basic soil processing. In the latter version, there was a reliable interaction of 
factors - surface treatment of fallow arable landand introduction of manure contributed to reducing the spread of wheat root rot by $24.4 \%$ and increased its yield by $14.0 \%$. Other scientists have noted the positive effect of organic fertilizer in reducing the risk of disease as well $[23,24]$, pointing out that the balanced supply of nutrients to plants correlates with the inhibitive biological effect on the root rot pathogen [25].

The selection of varieties is one of thetools of disease controlmanagement [26]. Our research is consistent with the above opinion. The results of testingthe new varieties of wheat are presented in the table. 3 .

Table 3. Spread of root rot and yields of new varieties of spring wheat, average 2017-2018.

\begin{tabular}{|l|c|c|c|c|}
\hline \multirow{2}{*}{ Varieties } & \multicolumn{2}{|c|}{ Spread of root rot, \% } & \multicolumn{2}{c|}{ Yields, t/ha } \\
\cline { 2 - 5 } & Average & $\begin{array}{l}\text { Difference } \\
\text { vs control }\end{array}$ & Average & $\begin{array}{c}\text { Difference } \\
\text { vs control }\end{array}$ \\
\hline $\begin{array}{l}\text { Tulunskaya } \\
\text { 11(control) }\end{array}$ & 42.5 & - & 2.93 & - \\
\hline Zoriana & 38.3 & -4.2 & 2.96 & 0.03 \\
\hline Marsianka & 29.5 & -13.0 & 3.11 & 0.18 \\
\hline $\begin{array}{l}\text { Least } \\
\begin{array}{l}\text { Significant } \\
\text { Difference } 05\end{array}\end{array}$ & \multicolumn{2}{|c|}{4.81} & \multicolumn{2}{|c|}{0.14} \\
\hline
\end{tabular}

Both new varieties, compared to the traditional variety Tulunskaya 11 in the bunching phase were less affected by the disease, but we can state it reliably only for the Marsianka variety. Its harvest yield was also $6 \%$ higher than that of the control variety.

A study of the timing of planting of the Tulunskaya wheat variety revealed that the degree of root rot damage depended on hydrothermal conditions of the year. Of the two years of research, May's weather conditions were tougher in 2018 due to drought, which contributed more to the development of common spring wheat root rot. The results averaged for two years are shown in table 4 .

Table 4. The spread of root rot and wheat yields of the Tulunskaya 11 variety, depending on the date of planting, average 2017-2018.

\begin{tabular}{|l|c|c|c|c|}
\hline \multirow{2}{*}{$\begin{array}{l}\text { The date of the } \\
\text { planting }\end{array}$} & \multicolumn{2}{|c|}{ Spread of root rot, \% } & \multicolumn{2}{c|}{ Yields, t/ha } \\
\cline { 2 - 5 } & Average & $\begin{array}{c}\text { Difference } \\
\text { vs control }\end{array}$ & $\begin{array}{c}\text { Ave- } \\
\text { rage }\end{array}$ & $\begin{array}{c}\text { Difference } \\
\text { vs control }\end{array}$ \\
\hline May 15 & 27.8 & - & 2.95 & - \\
\hline May 20 & 28.2 & 0.4 & 3.00 & 0.05 \\
\hline May 25 & 42.4 & 14.6 & 3.10 & 0.15 \\
\hline May 30 & 51.8 & 24.0 & 2.70 & -0.5 \\
\hline $\begin{array}{l}\text { Least } \\
\text { Significant } \\
\text { Difference05 }\end{array}$ & \multicolumn{2}{|c|}{9.35} & \multicolumn{2}{|c}{0.11} \\
\hline
\end{tabular}

Late planting dates in the third decade of May led to a significant increase in the root rot of wheat in the bunching phase by $52.5-86.3 \%$ compared to the early planting date of May 15.The sowing date of May 25 turned out to be more optimal, aswith which, despite the high spread of the disease, a reliable yield increase of $0.15 \mathrm{t} /$ ha was nevertheless obtained.

\section{Conclusion}

Thus, in the production of organic wheat in the foreststeppe zone of the Irkutsk region, it is quite possible to limit root rot by agrotechnical methods:

- phytosanitary predecessors such as clover green manure and fallow arable land processes with a disc harrow to a depth of $10-12 \mathrm{~cm}$ as the main treatment of the soil and with introduction of 30 tons of manure per hectare;

- using a sustainable variety of Marsianka spring wheat; - choosing the optimal planting time.

The author thanks A.I. Kuznetsov, F.S. Sultanov, V.I. Solodun, A.A. Iudin, A.M. Zaitsev, E.N. Diachenko, O.G. Diatlova, A.T. Shevelev, scientists of the Irkutsk Research Institute of Agriculture, for their help and the opportunity to conduct research.

\section{References}

[1] A.Kh. Zanilov, O.S. Melentyev, A.M. Nakaryakov,Organization of organic agricultural production in Russia: a reference manual, FSINI "Rosinformagroteh", Moscow, 3 (2018).

[2] Organic Word: "The World of Organic Agriculture" at BIOFACH 2019, Regulations and Standards 2019, Research Institute of Organic Agriculture, FiBL[Electronic resource]. Available at: $\quad$ https://orgprints.org/33355/1/huber-2019standards-regulations.pdf (Accessed: 03.03.2020).

[3] Organic Europe:Organic Agriculture Worldwide: Key results from the FiBL survey on organic agriculture worldwide 2019, Part 1: Global data and survey background, Frick, Switzerland: Research Institute of Organic Agriculture, FiBL(2019) [Electronic resource]. Available at: https://www.organic-world.net/fileadmin/ documents/yearbook/2019/FiBL-2019-Global-data2017.pdf(Accessed: 03.03.2020).

[4] P.A. Chekmarev, A.P. Glinushkin, V.I. Startsev, Achievements of science and technology of the agro-industrial complex, 3, 5 (2018).

[5] Dun-chun He, Jia-sui Zhan, Lian-huiXie, Journal of Integrative Agriculture, 15, 4, 705 (2016).

[6] BitaNaseri, RoghaieHemmati, Rhizosphere, 4, 48 (2017).

[7] V.A. Chulkina, E.Yu. Toropova, Yu.I. Chulkin, G.Ya. Stetsov, Agrotechnical method of plant protection, Information and Marketing Center "Marketing", Moscow, LLC "UKEA Publishing House",Novosibirsk, 336 (2000).

[8] E.N. Kiseleva, A.A. Razina, Yu.S. Korzinnikov, A.L. Telyatko, Bulletin of the Russian Academy of Agricultural Sciences, 3, 42 (2010).

[9] A.A. Razina, S.A. Lutsenko, Yu.S. Korzinnikov, Bulletin of the IRIA, 30, 14 (2008). 
[10] N.G. Vlasenko, Achievements of science and technology of the agro-industrial complex, 4, 25 (2016).

[11] K.A. Congreves, A. Hayes, E.A. Verhallen, L.L. Van Eerd, Soil \& Tillage Research, 152, 17 (2015).

[12] R. Tao, Y. Liang, S.A. Wakelin, G. Chu, Applied Soil Ecologi., 96, 42 (2015).

[13] H. Wang, X. Li, X. Li, J. Wang, X. Li, Q. Guo, Z. Yu, T. Yang, H. Zhang, Soil \& Tillage Research, 196, 104452 (2020).

[14] V.I. Tansky, M.M. Levitin, T.I. Ishkova, V.I. Kondratenko, Plant Protection and Quarantine, 3, 51 (2002).

[15] State methodology of testing cropvarieties. Second issue: Grains, cereals, legumes, corn and fodder crops, Agropromizdat, Moscow, 5-23 (1989).

[16] V.A. Dospekhov, Method of field experiments, Agropromizdat, Moscow(1985).

[17] O.D. Sorokin, Software complex, Snedecor V. 5 Applied statistics for researchers, Novosibirsk (1992).

[18] V.Campanella, C.Mandalà, Vincenzo Angileri, Claudia Miceli, Crop Protection, 130, 105073 (2020).

[19] W.F. Schillinger, T.C. Paulitz, Field Crops Research, 223, 26 (2018).

[20] D. Drakopoulos, A.Kägi, A.Gimeno, J. Six, E. Jenny, H.-R.Forrer, T. Musa, G.Meca, S.Vogelgsang, Field Crops Research, 246, 107681 (2020).

[21] L. Zou, A. Tuulos, A.Mikkonen, F.L. Stoddard, K.Lindström, M.H. Kontro, N. Koponen, Pirjo S.A Mäkelä, European Journal of Soil Biology, 69, 41 (2015).

[22] L.D. Bainard, A. Navarro-Borrell, C. Hamel, K. Braun, K. Hanson, Y.Gan, Agriculture, Ecosystems and Environment, 240, 206 (2017).

[23] K.Gleń-Karolczyk, E. Boliglowa, J.Antonkiewicz, Applied Soil Ecology, 129, 43 (2018).

[24] J. Ding, X. Jiang, D. Guan, B. Zhao, M. Ma, B. Zhou, F. Cao, X. Yang, L. Li, J. Li, Applied Soil Ecology,111, 114 (2017).

[25] M.T. Löbmann, R.R. Vetukuri, L. de Zinger, B.W. Alsanius, L.J. Grenville-Briggs, Abigail J. Walter, Applied Soil Ecology, 107, 57 (2016).

[26] A.G. Verrell, S. Simpfendorfer, K.J. Moore, Soil \& Tillage Research, 165, 16 (2017). 